\title{
Notes on Contributors, volume 2
}

Eirini Afentoulidou is a Postdoc Researcher at the Institute for Medieval Research, Division of Byzantine Research of the Austrian Academy of Sciences, specialising in Byzantine language, literature and mentality. After studying Greek Philology at the Aristoteles University of Thessaloniki (2000) she obtained her doctoral degree at the University of Vienna (2005). She is author of several publications on Byzantine language and style, hymnography, images of afterlife and prayerbooks, especially prayers for childbed.

Kurt Appel is Professor for Fundamental Theology at the University of Vienna and the director of the interdisciplinary research centre "Religion and Transformation in Contemporary Society”. He was visiting professor at the universities of Trento, Milan and Bologna. His research areas are new humanism, eschatology, philosophy of history, German idealism (especially Hegel's speculative writings), postmodern philosophy, theology and politics and the question of God. His recent publications include Tempo e Dio. Aperture contemporanee a partire da Hegel and Schelling (Queriniana, 2018) and "Das Dieses ist ein Baum. Der absolute Geist als freies Dasein der Wirklichkeit” (In: Objektiver und absoluter Geist nach Hegel (Brill, 2018). He is the editor of the open access journal J-RaT (Journal of Religion and Transformation) and author and editor of numerous monographs, articles and scientific anthologies (in German, Italian and English).

Frederick Shih-Chung Chen is a research associate and was the Sheng Yen Postdoctoral Research Fellow in Chinese Buddhism (2015-2017) at the Department of Philosophy at the National Chengchi University, Taipei. He obtained his PhD in Oriental Studies at the University of Oxford in 2010. His main academic interests are the history and archaeology of early and medieval Chinese Buddhism.

Miriam Czock studied History and Philosophy at the Ruhr-University Bochum. She obtained her doctoral degree with a study on Gottes Haus. Untersuchungen zur Kirche als heiligem Raum von der Spätantike bis ins Frühmittelalter. She is a senior lecturer at the University of Duisburg-Essen. Her main research interest lies in the periods of early and high medieval Europe, specifically on the emergence of a Christian concept of society that is rooted in intellectual models of space and time. Other fields of interest are sacrality, legal-practices as well as the workings of early medieval local society. She has published widely on all these topics and together with Anja Rathman-Lutz she has edited the volume ZeitenWelten. Zur Verschränkung von Zeitwahrnehmung und Weltdeutung (750-1350) (Böhlau, 2016). 
Marilyn Dunn is Honorary Senior Research Fellow in Medieval History in the School of Humanities, College of Arts, at the University of Glasgow. She is the author of The Emergence of Monasticism (Blackwell, 2003); The Christianization of the Anglo-Saxons (Continuum, 2009); Belief and Religion in Barbarian Europe (Bloomsbury, 2013); and Arianism (Arc Humanities Press, forthcoming). Her current research project is Ex-voto: A Cognitive History.

Johann Heiss is Senior Researcher at the Institute for Social Anthropology (ISA) at the Austrian Academy of Sciences in Vienna. After studying Classical Philology and Arabic language he finished his study of Social and Cultural Anthropology 1998 with a dissertation on the first imam of the Yemen and the tribal situation in the tenth century. He carried out field research in Saudi-Arabia (together with Walter Dostal and Andre Gingrich), Yemen (together with Andre Gingrich), Indonesia (with Martin Slama) and Lower Austria. He was project leader of "Shifting Memories, Manifest Monuments", addressing the memory of the Turks in Central Europe (ended in 2013); coordinator on the South Arabian part of the SFB "Visions of Community" project. His most recent publications include "Migrations and Federations: The Origins of the Tribal Federation of Khawlān According to al-Hamdānī” (In The Medieval History Journal, 2018), and, together with Eirik Hovden, "Competing Visions of Community in Medieval Zaydi Yemen" (In Journal of the Economic and Social History of the Orient, 2016).

Rutger Kramer finished his PhD at Freie Universität in Berlin, and has worked as a Postdoc Researcher within the SFB "Visions of Community" project at the Institute for Medieval Research since 2011, where he also finished his monograph, Rethinking Authority in the Carolingian Empire (Amsterdam University Press, 2019). Since 2019, he is employed as a lecturer in Medieval History at the Radboud University in Nijmegen. His research revolves around all aspects of Carolingian intellectual culture, from monastic reforms to the development of imperial ideologies, and from hagiographical traditions to the way historiography was used to shape the present and the future of the Frankish Empire.

Pia Lucas is researcher and lecturer in Late Antiquity and the early Middle Ages at Freie Universität Berlin. In her dissertation, she is currently examining the inclusion of saints from across the Mediterranean in the works of the sixth-century bishop Gregory of Tours. Over the course of two research projects, she worked on processes of exchange across the late antique and early medieval Mediterranean and co-edited the volume The Merovingian Kingdoms and the Mediterranean World: Revisiting the Sources (Bloomsbury, 2019) together with Stefan Esders, Yitzhak Hen and Tamar Rotman. 
Bernhard Scheid (PhD University of Vienna) is a Senior Research Fellow at the Austrian Academy of Sciences focusing on the history of Shintō. Major publications include a monograph on Yoshida Shintō (Der Eine und Einzige Weg der Götter, VÖAW, 2001) and a couple of edited volumes on Japanese religious history ranging from medieval to modern Japan. Recently, he initiated a project on Shintō in the early Tokugawa period, supported by the Austrian Science Fund (FWF), which is presently carried out under his supervision.

Marc Tiefenauer received his PhD in Indology from the University of Lausanne. He is the scientific librarian in charge of the Oriental collections (Sanskrit, Hindi, Urdu, Tibetan, Chinese) of this university. His research explores the eschatological representations in South Asian religions, basing his studies on primary sources in Sanskrit, Pali, Buddhist Chinese, Ardhamagadhi, Braj and Persian. He also has an interest for the translation and the reception of Sanskrit texts into Persian.

Roberto Tottoli is Professor of Islamic Studies at the Università di Napoli L'Orientale, Dipartimento Asia, Africa e Mediterraneo, where he obtained his PhD in 1996. He has published on early Islamic literature, focusing on patriarchs and prophets in the Qur'an and medieval literary genres (Biblical Prophets in the Qur'an and Muslim Literature, Curzon Press, 2002; The Stories of the Prophets by Ibn Mutarrif al-Tarafi edited with an introduction and notes by Roberto Tottoli, Klaus Schwarz Verlag, 2003). He has also edited works on contemporary Islam (Routledge Handbook of Islam in the West, Routledge, 2015). His most recent book deals with the Latin translation of the Qur'an by Ludovico Marracci (d. 1700) (co-authored with Reinhold F. Glei, Ludovico Marracci at Work: The Evolution of his Latin Translation of the Qur'ān in the Light of his Newly Discovered Manuscripts with an Edition and a Comparative Linguistic Analysis of Sura 18, Harrassowitz, 2016).

Martin Treml is a Postdoc Researcher in history and in religion and culture. He graduated from Freie Universität Berlin (1996) and has, since 2000, been working as a Senior Research Fellow and academic coordinator of research projects at the Center for Literary and Cultural Research Berlin (ZfL). He was fellow of academic institutions in Jerusalem, London, Berlin, Weimar, Stanford, Innsbruck and Vienna. His research focuses on the history and methodology of cultural research around 1900 and on theory and figures of Western religions. He has undertaken a long-time research project on Jacob Taubes and has edited Taubes' correspondence with Carl Schmitt (Fink Verlag, 2011) and Hans Blumenberg (Suhrkamp Verlag, 2013) as well as a volume including Taubes' selected writings (Fink Verlag, 2017; all with Herbert Kopp-Oberstebrink).

Graeme Ward is a British Academy Postdoctoral Fellow at the Faculty of History, University of Oxford. Prior to taking up this position in January 2018, he completed 
a PhD at the University of Cambridge (2014) and then spent several years working as a researcher at the Institute for Medieval Research of the Austrian Academy of Sciences, Vienna. Between holding an OeAD-Ernst Mach Grant (2013-2014) and a Leverhulme Study Abroad Studentship (2015-2017) while in Vienna, he was also employed on the SFB "Visions of Community" project. His research focuses on Carolingian intellectual culture.

Immo Warntjes is Ussher Assistant Professor in Early Medieval Irish History at Trinity College Dublin. His research interests in early medieval history are science and time-reckoning, the transmission of ideas, the Easter controversy, monastic teaching, and kingship. He is currently leading the project "The Irish Foundation of Carolingian Europe: The Case of Calendrical Science”, funded by the Irish Research Council Laureate Award scheme.

Christian Zolles is a Postdoctoral Research Assistant at the Institute of German Studies at the University of Vienna and a reader in Modern German Literature. He has obtained his PhD in German Studies and History at Vienna, with fellowships at the University of Glasgow and the Center for Literary and Cultural Research Berlin (ZfL). In his research, he is working at the intersection of literary studies, cultural theory and digital humanities. He is author of Die symbolische Macht der Apokalypse. Eine kritisch-materialistische Kulturgeschichte politischer Endzeit (De Gruyter, 2016), co-editor of the series Cultural History of Apocalyptic Thought (De Gruyter) and author and co-editor of several publications on digital humanities in the field of German Studies. 